\title{
Carbon Sequestering and Green Roof Technology: A Benefit Cost Analysis
}

\author{
Douglas Auld \\ Department of Economics and Finance, University of Guelph \\ Guelph, ON N1G 2W1, Canada \\ E-mail: dauld@uoguelph.ca \\ Jeremy Wright \\ Department of Economics and Finance, University of Guelph \\ Guelph, ON N1G 2W1, Canada
}

Received: August 3, 2017 Accepted: December 1, 2017

doi:10.5296/emsd.v7i1.12396 URL: https://doi.org/10.5296/emsd.v7i1.12396

\begin{abstract}
The installation of a green roof on residential buildings affords the opportunity to sequester carbon from the atmosphere. The cost of incorporating green roofs in the construction of a family home or modifying an existing home is significant and the private benefits are rather small. Carbon reduction does have a value recognized by all levels of government in Canada. In this paper we calculate the cost of installing a green roof on a two vehicle garage in the Province of Ontario using current building costs. Utilizing data on the private costs and private benefits, the estimated NPV of a green roof over a 35 year period is negative. Once the value of carbon sequestering is introduced in the model, the NPV is positive, suggesting that subsidizing green roof construction is an efficient method in any government's quiver to encourage a reduction in GHG emission.
\end{abstract}

Keywords: Environmental economics, Carbon sequestering, Green roof technology, Benefit-cost

\section{Introduction}

Green roof technology is a term applied to growing vegetative matter on the roof of any free-standing structure. The idea dates from the Hanging Gardens of Babylon in 500 BC. (Stormwater Institute, 2016) In the past two decades, a significant body of research has 
developed illustrating the economic and environmental benefits of green roof technology. (Bianchini and Hewage, 2012) Several studies have utilized mathematical models to calculate the net present value (NPV) of one or more forms of green roof technology. (Carter and Keeler, 2008, Nurmi, et al, 2013, Clark, Adriaens and Talbot, 2008)

Employing the basic principles of benefit-cost analysis, this paper focuses on the application of green roof technology to residential vehicle garages in new home construction to accommodate efficient green roof technology in Ontario, Canada. Detailed costing is used to estimate the fixed capital cost of a green roof along with estimates of the annual maintenance cost to arrive at life-cycle cost of a two vehicle, garage-based green roof. Of particular important is our approach to capture the key public and private monetary benefits of a green roof, particularly the GHG reductions afforded by green roofs and private benefits not found in previous applied studies of green roof construction. The private and public benefits are calculated over the expected life of the roof to arrive at a NPV estimate. Not unexpected, the dollar-value results are sensitive to estimates of the personal monetary value attributed to living in a home with a green roof garage and the monetary value attributed to the carbon sequestered by the green roof.

\section{Public Benefit Case for Green Roofs}

Escalating concerns associated with global warming have generated a wide range of behavioral and economic changes to reduce carbon dioxide equivalent emissions $\left(\mathrm{CO}_{2 \mathrm{ev}}\right)$. In Canada, federal and provincial government have implemented polices to curb emissions that cause GHG. Individuals, however, can exercise choice in consumption behavior to reduce carbon emissions. Building is one example where individuals and firms can make a market choice contributing to a low-carbon economy and achieve other public goals such as storm water management. The desire on the part of homeowner--and business-- to do so has led to the development of green building focusing on innovations in building construction that appear aesthetically attractive and include features that reduce the carbon footprint of a house or place of business. In Canada, the application of this technology was demonstrated initially in commercial buildings. ${ }^{1}$ The paucity of green roofs in residential homes and suburban developments is puzzling considering its growing use in the commercial building market. The capital cost of applying the technology to a house in addition to on-going maintenance may limit the attractiveness of a residential green roof. Design aesthetics may also hinder the adoption of such technology. While the private and public benefits of green roofs on commercial buildings in terms of energy saving and water retention are apparent--and in some instances significant-- they are not as evident in single family dwellings.

Green roof design is categorized by extensive, semi-intensive and intensive, based on the substrate depth and the vegetation to be grown on the roof. (Oberndorfer et al. 2007) Extensive roofs are the most common versions of green roof technology, requiring the least maintenance and no permanent irrigation. Semi-intensive roofs involve a growing medium or substrate ranging from 15 to $30 \mathrm{~cm}$ in thickness allowing the roof to sustain much richer

\footnotetext{
1 A study in 2007 estimating the costs associated with green roofs on municipal commercial buildings identified the major benefits as increasing the life of the roof and energy savings. (Toronto, 2007)
} 
ecology and retain a larger volume of storm water run-off. This roof allows a larger diversification of plants, with soil depths that are capable of supporting vegetation for food consumption. An intensive green roof is identified by the variety of vegetation that can be supported on the roof including herbaceous plants and trees. Such roofs support a landscape with high biodiversity requiring advanced irrigation systems and therefore professional and continuous maintenance services. (Stormwater Institute, 2016)

Life cycle estimates of the NPV of a green roof require establishing the life expectancy of the roof. Green roofs protect the base layer of a flat roof from damages, taking the brunt forces of nature, an attractive feature in the harsh Canadian climate. The green roofs act as a barrier from the roofing material, with a portion of the water and heat retained in the vegetation and substrate. Green roofs in Europe have lifespans of up to 50 year while the expected life for a green roof in Ontario is 35 years. (Toronto, 2007) ${ }^{2}$

\section{Benefits and Costs of Green Roofs}

\subsection{Benefits to Homeowner}

The psychological benefits of green roofs are manifold (Gillis and Gatersleben, 2015),

including a 'warm glow' feeling that one is contributing to improving the environment of the community they live in. (Orbendorfer, 2007) However, it is difficult to measure this increased utility in dollar terms. The fact that a person opts to build a green roof and is aware of the maintenance costs suggests that the personal, intrinsic benefits are at least equal to the maintenance cost. These benefits are captured, at least to some extent, in the increased value of a residential property that includes a green roof. Two hedonic pricing studies, one in Toronto and one in Quebec City, suggest that a green roof adds between 6 and $15 \%$ to the life-time value of a residential property. (Peck et al, 1999 and Desrosiers, et al, 2002) For the purpose here we assume a very conservative property appreciation due to green roof technology of 3 per cent.

\subsection{Public Benefits}

Green roofs provide benefits to both the local and global community by enriching the biodiversity of a region, delaying the storm peak to the drainage system, diminishing the runoff quantity, removing pollutants from the air and improving the quality of water run-off. (Li and Yeung, 2014) Of particular interest in this study is the ability of a green roof to offset the loss of carbon sequestering properties of soil and vegetation forfeited due to building construction. Terrestrial carbon is sequestered primarily through soils, plants and most importantly trees, all of which convert the carbon back into readily available oxygen. Benefit cost analysis requires accounting for this by estimating the ability of green roof to sequester carbon and assign a monetary value to the weight of carbon removed.

All vegetation will sequester carbon. Semi-intensive green roofs provide an opportunity to plant and grow both grass, sedums, perennials and small shrubs. Focusing on plant growth in

\footnotetext{
2 There is a consensus that green roofs extend the life of a roof. In Germany, it is estimated that green roofs double the life of a roof. (Porsche and Kohler. 2003)
} 
Ontario, with its harsh winters and sporadic rainfall through the fall, summer and spring, sedums are used for the initial carbon sequestering calculations. Sedums are selected because they are perennial, provide a range of species and not difficult to maintain. (Carter and Butler, 2008) The coverage and hardiness of sedums makes them ideal for owners of gardens who look for low maintenance costs, especially on top of a garage roof.

A study of the carbon benefits from sedums on a green roof in a semi-intensive green roof was done at Michigan State University. (Getter and Rowe, 2009) The research covered a two year period in a climate similar to southern Ontario. The sedums studied were Sedum Acre, Sedum Album, Sedum Kamtschaticum, and Sedum Spurium providing a base average for the carbon sequestered amongst the most common sedums used in extensive and semi-intensive green roofs without irrigation systems in place. (Getter and Rowe, 2009) The study focused on a minimum substrate depth for a green roof of $6 \mathrm{~cm}$ and the research procedure averaged the carbon sequestered in the soil beneath each sedum, the biomass of the sedums in the soil or the roots, as well as the carbon captured in the biomass of the sedums above the soil.

On average, carbon captured (C) by the individual components of the sedum green roof for the first-year were; $100 \mathrm{~kg} \mathrm{C} / \mathrm{m}^{2}$ for substrate content, $168 \mathrm{~g} \mathrm{C} / \mathrm{m}^{2}$ for above ground sedum biomass, and $107 \mathrm{~g} \mathrm{C} / \mathrm{m}^{2}$ of above ground sedum biomass, totalling to an average carbon sequestering of $375 \mathrm{~g} \mathrm{C} / \mathrm{m}^{2}$ (or $0.076 \mathrm{lbs} \mathrm{C} / \mathrm{ft}^{2}$ ) for a sedum-based extensive green roof. (Getter and Rowe, 2009) A more recent study focused on the carbon sequestering differences between a green roof plant community and ground landscape, considering 13 different landscapes over a three year period. (Whittinghill, et al, 2014) After a two-year period, the sedum and grass green roof sequestered $4.67 \mathrm{C} \mathrm{kg} / \mathrm{m}^{2}$, suggesting the greater substrate depth, increased complexity of the plant system and more advanced irrigation system, enhanced the carbon sequestering significantly. Although this approach increased the cost of a green roof project (discussed later), it was necessary to install irrigation mats in conjunction with deeper soil depth to maximize carbon sequestering. Applying these results to a seven square meter roof, approximately $168.48 \mathrm{~kg}$ of carbon dioxide are would be sequestered per year. If a green roof were used to grow vegetables, the carbon sequestering would be approximately 20 per cent lower. (Michigan State University, 2009)

\section{Costs}

\subsection{Capital Costs of a Conventional Two-Car Garage (No Green Roof)}

Costs estimates for a two car garage were provided by the industry and quoted in Canadian dollars per square foot. For a typical, non-custom home and garage design, we assume assign costs based on square footage, assuming the building is a basic design that meets provincial building code. The base garage in this study includes; two garage doors, one door leading to house, one door leading outside, electrical, spray foam insulation and most important a basic asphalt flat roof. Based on Ontario averages, an attached two car garage would cost (for materials and labour) $\mathrm{C} \$ 34.5 \mathrm{ft}^{2}$ or $\$ 16,698$ for a 484 square foot garage. (https://www.homeadvisor.com/cost/garages/build-a-garage) 


\subsection{Capital Cost of Garage with a Green Roof}

The major fixed costs for the green roof begin is framing the garage, due to the requirements for the load bearing portion of the roof. In place of the common wood joists running parallel to the ground for a flat roof, stronger weight-bearing engineered joists are used for a green roof. These types of joists are crucial for a green roof, especially in Ontario climate which already requires a $22 \mathrm{lb} / \mathrm{ft}^{2}$ load capacity for a non-skid, $0.25 / 12$ pitched flat roof in Ontario. (Jacubus Engineering, 2016) For the semi-intensive green roof, requiring a load capacity of $40 \mathrm{lb} / \mathrm{ft}^{2}$, the spacing between joists is reduced from the $24 \mathrm{inch}$ span from the original roof to a 16 inch spans. (Roof Trust Span Tables, 2016) This would increase the number of joists from approximately 10 (2"x 10" x 22') wooden joists, to 14 (2-1/2"x9-1/2"x22') engineered TJI 210 joists. ) The costs of the engineered joists is $\$ 4 \times 18 \times 14=\$ 1008$, compared to $\$ 3 \times$ $18 \times 10=\$ 540$ for a standard garage. (Home Hardware, 2016) This will add approximately $\$ 468$ to the fixed costs of constructing a green roof.

We assume a standard, flat top asphalt roof base followed by waterproofing membrane, a drainage layer, a root-resistant layer, the growing medium, and finally the vegetation. For a higher end, semi-intensive green roof providing irrigation and soil depth that maximizes the carbon sequestering, the average price in Canada would be an additional $\$ 25 \mathrm{ft}^{2}$ planted or $\$ 11,025$ for the green roof. (Green Infrastructure Research and Incentives Workshop, 2016) The marginal cost of the roof includes the additional cost of material for framing the roof to handle the green technology, as well as the additional cost of materials and labour for constructing the green roof. Assuming no need to make major repairs over the life of the roof, the capital or fixed cost for a green roof is $\$ 468+\$ 11,025=\$ 11,493 .{ }^{3}$ Given that Toronto is the largest jurisdiction in Ontario, we employed the Toronto subsidy of $\$ 8.33 \mathrm{ft}^{2}$ subsidy and reduce the fixed cost for a green roof from $\$ 11,493$ to $\$ 8,493$.

\subsection{Variable Cost}

The main variable cost associated with green roofs is the upkeep to maintain the roof including weeding, irrigating and debris removal. These costs are primarily impacted by the weather and vegetation planted on the roof. For the purpose of this analysis, the annual maintenance or variable cost is $\$ 220$, which is the industry average of $\$ 0.5 /$ square foot/year. (Living Roofs for Healthy Cities, 2016)

\section{Benefit-Cost Model}

Benefit-cost analysis is a framework where costs and benefits of an action are measured and expressed in comparable monetary terms. (Fields and Olewiler, 2015) This approach is applied to numerous potential environmental programs to determine the efficiency and effectiveness of a given policy. The major considerations in developing a model for this study were: life cycle analysis, the social rate of discount and the quantifying private and social benefits of green roofs. Installing and maintaining a green roof when building a garage or

\footnotetext{
${ }^{3}$ The actual fixed cost to the builder will be less due to municipal subsidies to encourage green roof construction. The nature of the incentive varies across municipalities. For example, the town of Caledon offers a percentage reduction in the local development charge. Kitchener provides grants up to $\$ 5,000$ for the construction of a green roofed building. The city of Toronto provides a reduction in the development charge and a subsidy of $\$ 75$ per square meter of green roof. (Toronto 2010)
} 
renovating an existing roof involves a one- time capital expenditure and on-going maintenance costs. The benefits from a green roof unfold over the life of the roof mandating that a benefit cost analysis of a green roof be framed over the life of the roof. The B-C model below follows the tradition of other studies. (Carter, T. and A. Keeler, 2008, and Bianchini, and Hewage, 2008) Selecting the appropriate social rate of discount is not straightforward. Conceptually, the social discount rate is the rate at which society is willing to trade a current benefit for future benefit. Selecting a specific figure is challenging, as Peter Spiro points out : "However, it is argued that the appropriate discount rate is not fixed, and varies with financial market conditions imply that a real discount rate of about 5 percent would have been appropriate for provincial government benefit/cost analysis of investment projects." (Spiro, 2010) The final major challenge is imputing monetary value to the improvement in air quality due to green roof technology.

The B-C model for this analysis is

$N P V g r=\sum_{1}^{35} \frac{B i}{1+r}-\sum_{1}^{35} \frac{C j}{1+r}$

Where $N P V g r=$ net present value of a green roof as described above

$\sum_{1}^{35} \frac{B i}{1+r}=$ discounted benefits of a green roof

$\sum_{1}^{35} \frac{C j}{1+r}=$ discounted costs of a green roof

$\mathrm{B}_{1}=$ Annual value of the sequestered carbon with carbon priced at $\$ 10$ per tonne $=168.48 \mathrm{~kg} \mathrm{X}$ $\$ 0.05=\$ 8.42$.

$\mathrm{B}_{2}=$ Assumed annual aesthetic value of green roof $=\$ 220$.

$\mathrm{B}_{3}=$ present value of the straight-line, 3 percent appreciation of the green roof home $=\$ 5,600$.

$\mathrm{C}_{1}=$ Annual depreciated fixed cost of the green roof assuming straight-line depreciation= $\$ 242.66$.

$\mathrm{C}_{2}=$ Annual cost of maintaining the green roof $=\$ 220$

$\mathrm{r}=$ discount rate $=5$ percent

\section{Results and Discussion}

Installing a green roof on a two vehicle garage in Ontario, paid entirely by the home owner, yields a significant negative present value return of - $\$ 4157$ over 35 years taking into account a monetary value for the aesthetics of a green roof valued at $\$ 220$ per home owner, a municipal subsidy and a federal and/or provincial payment subsidy to the home owner for carbon sequestered at a rate of $\$ 10$ per ton. However, if we take into account a very modest (3 per cent) appreciation of the value of a $\$ 400,000$ green roof house with a green roof, the net present value is $\$+1442$.

If the price of carbon is set at $\$ 50$ per ton the NPV increases to $\$+2800$. The rationale for this assumption is two-fold. First, the Canadian government has announced its intention to 
increase the price of carbon to $\$ 50$ per ton in the next 10 years. In the longer run, it is likely to be higher than $\$ 50$. What it will be in 35 years is impossible to predict but setting a fixed price of $\$ 50$ per ton over the life of the green roof is not unreasonable. Second, accounting practices in private corporations globally include accounting for the cost of carbon emissions in excess of $\$ 50$ per ton. Oil companies have recently incorporated a carbon price of $\$ 60$ per ton in their social accounting. (Shapiro, 2014)

The federal government of Canada is committed under the Paris Agreement to a substantial reduction in GHG emissions between now and 2050. The task is a challenging one and the government has established a long list of initiatives to achieve the goal. The results of this analysis of the benefits and costs of green roof technology suggest that one simple instrument in the federal and/or provincial government tool kit to reduce GHG should be a subsidy to homeowners or directly to developers for the construction of a green roof.

\section{References}

Bianchini, Fabricio \& Kasun Hewage (2012). Probabilistic social cost-benefit analysis of green roofs: A lifecycle approach, Building and environment, 58, 152-162, https://doi.org/10.1016/j.buildenv.2012.07.005

Carter, Timothey \& Colleen Butler (2008). Ecological impacts of replacing traditional roofs with green roofs in two urban areas, Cities and the Environment, 1(2).

https://doi.org/10.15365/cate.1292008

Clark, C., Adriaens, P., \& Talbot, FB. (2008). Green Roof valuation: a probabilistic economic analysis of environmental benefits, Environmental Science Technology, 42(6), 2155-61. https://doi.org/10.1021/es0706652

Carter, T., \& Keeler, A. (2008). Life-cycle cost-benefit analysis of extensive vegetated roof systems, Journal of Environmental Management, 87(3).

https://doi.org/10.1016/j.jenvman.2007.01.024

Fields Barry \& Nancy Olewiler. (2015). Environmental Economics, McGraw Hill Canada, Toronto

Gillis, Kaitlyn \& Birgitta Gatersleben (2015). A Review of Psychological Literature on the Health and Wellbeing Benefits of Biophilic Design, Buildings, 5(3), 948-63.

https://doi.org/10.3390/buildings5030948

Green Infrastructure Research and Incentives Workshop, (2016), Retrieved from http://capitolgreenroofs.groupsite.com/calendar/soonest/449987

Getter, Kristin \& Bradley Rowe (2009). Substrate Depth Influences Sedum Plant Community on a Green Roof, Horticulture Science, 44(2), 401-407

Home Hardware (2016). Retrieved from

https://www.homehardware.ca/en/cat/.../Building-Supplies/Building-Materials

Jacubus Engineering (2016). Retrieved from 
http://mcgannconstruction.com/our-projects/jacobus-engineering

Li, W. C., \& Yeung, K. K. A. (2014). A comprehensive study of green roof performance from environmental perspective, International Journal of Sustainable Built Environment, 3(1), 127-134. https://doi.org/10.1016/j.ijsbe.2014.05.001

Michigan State University,

http://www.greenroof.hrt.msu.edu/research-projects/carbon-sequestration.html

Nurmi, Vaino, et al (2013). Cost-Benefit Analysis of Green Roofs in Urban Areas: Case Study in Helsinki, Finnish Meteorological Institute, Report 2013:2. ISSN 9782-6079

Oberndorfer, Erica et al. (2007). Green Roofs as Urban Ecosystems: Ecological Structures, Functions and Services, BioScience, 57(10). https://doi.org/10.1641/B571005

Peck, Steven \& Chris Callaghan (1999). Status Report on Benefits, Barriers and Opportunities for Green Roof and Vertical Garden Technology Diffusion, Retrieved from https://www.nps.gov/tps/sustainability/greendocs/pecksm.pdf

Porsche, U., \& Kohler, M. (2003). Life Cycle Costs of Green Roofs: A Comparison of Germany, USA, and Brazil, World Climate and Energy Event, December 1-5, Rio de Janeiro, Brazil.

Spiro, Peter (2010). The Social Discount Rate for Provincial Government Investment Projects, in Discount Rates for the Evaluation of Public Private Partnerships (ed. David Burgess and Glenn Jenkins), Queens University, Kingston, Ontario, Canada

Shapiro, Mark (2014). Oil Companies Quietly Prepare For a Future of Carbon Pricing", Yale Environment 360, September, Retrieved from

http://e360.yale.edu/features/oil_companies_quietly_prepare_for_a_future_of_carbon_pricing

Stormwater Report (2016). From planning to permitting, stormwater apps help industrial property owners, Stormwater Institute, December.

Toronto (2007). An Economic Analysis of Green Roofs, Toronto and Region Conservation and Sustainable Technologies Evaluation Program, July

Toronto (2016). Planning and Growth Management Department, City Planning Division, Toronto, Ontario

Whittinghill, Leigh, Bradley Rowe, Robert Schutzki \& Bert Cregg (2014). Quantifying carbon sequestration of various green roof and ornamental landscape systems, Landscape and Urban Planning, 123, 41-48. https://doi.org/10.1016/j.landurbplan.2013.11.015

\section{Copyright Disclaimer}

Copyright for this article is retained by the author(s), with first publication rights granted to the journal.

This is an open-access article distributed under the terms and conditions of the Creative Commons Attribution license (http://creativecommons.org/licenses/by/3.0/). 